\title{
Effect of Inspiratory Muscle Training on Anxiety and Depression in Patient with COPD that Received Pursed Lip Breathing
}

\author{
Yeanita, Rahmi Isma Asmara Putri
}

Department of Physical Medicine and Rehabilitation, Diponegoro University, Kariadi General Hospital, Semarang, Indonesia

\begin{abstract}
Introduction: The presence of anxiety and depression in patients with Chronic Obstructive Pulmonary Disease (COPD) is often associated with greater disability, higher rates of exacerbations, increased hospitalization and mortality. Many types of breathing exercises, such as Pursed Lips Breathing (PLB), Diaphragmatic Breathing (DBE), Respiratory Muscle Training (RMT), have been reported positive physiological effects to reduces breathlessness, anxiety and depression in patients with COPD. This study aims to determine the effect in anxiety and depression after intervention of Inspiratory Muscle Training (IMT) in COPD patients that received PLB.

Methods: An experimental pre and post randomly study design, in August - September 2019. Control group and experimental group each performed PLB exercises while the experimental group got additional IMT. To evaluate anxiety and depression status, Hospital Anxiety and Depression Scale (HADS) was used.
\end{abstract}

Results: Twenty subjects with COPD were recruited, no significant differences of HADS score between both groups. After 6 weeks of intervention, the HADS score in each group decreased significantly, with delta of HADS score in experimental group was greater than the control group $(\mathrm{p}<0.05)$.

Conclusion: Improvement of HADS scores after additional IMT was better than PLB only in COPD patients.

Keywords: chronic obstructive pulmonary disease; hospital anxiety and depression scale; inspiratory muscle training; pursed lips breathing. 


\section{ABSTRAK}

Pendahuluan: Kecemasan dan depresi pada pasien Penyakit Paru Obstruktif Kronik (PPOK) sering dikaitkan dengan disabilitas lebih berat, tingginya angka eksaserbasi, tingginya angka rawat inap dan kematian. Berbagai jenis latihan nafas seperti Pursed Lips Breathing (PLB), pernafasan diafragma, penguatan otot pernafasan dilaporkan memiliki efek psikologikal positif dalam mengurangi sesak, cemas dan depresi pada pasien PPOK. Penelitian ini bertujuan untuk mengetahui perbaikan cemas dan depresi setelah pemberian Inspiratory Muscle Training (IMT) pada pasien dengan PPOK yang menerima latihan PLB.

Metode: Desain penelitian pre dan post intervensi acak, pada bulan Agustus - September 2019. Kelompok kontrol dan intervensi masing-masing diberikan latihan PLB, dimana kelompok intervensi mendapatkan tambahan latihan IMT. Hospital Anxiety and Depression Scale (HADS) digunakan untuk mengevaluasi status cemas dan depresi sebelum dan sesudah intervensi.

Hasil: Dua puluh subjek dengan PPOK direkrut, tidak ada perbedaan bermakna pada skor HADS diantara kelompok kontrol dan kelompok intervensi. Setelah 6 minggu intervensi, didapatkan penurunan bermakna skor HADS pada masing-masing kelompok, dimana selisih skor HADS pada kelompok intervensi lebih besar dibandingkan kelompok kontrol $(\mathrm{p}<0.05)$.

Kesimpulan: Perbaikan skor HADS setelah penambahan latihan IMT lebih besar dibandingkan hanya dengan latihan PLB pada pasien PPOK.

Kata Kunci: hospital anxiety and depression scale; inspiratory muscle training; penyakit paru obstruktif kronik; pursed lips breathing

\section{Correspondent Detail:}

\section{Yeanita}

Email: yeyen.jan18@gmail.com

Department of Physical Medicine and

Rehabilitation, Faculty of Medicine,

Diponegoro University,

Kariadi General Hospital, Semarang,

Indonesia

\section{INTRODUCTION}

Chronic Obstructive Pulmonary Disease (COPD) is an irreversible lung disease characterised by dyspnea, chronic cough and sputum production. It is a major cause of mortality and morbidity worldwide and predicted to become the third leading cause of death globally by $2030 .^{1}$ Anxiety and depression are common in patients with COPD patients, they often undiagnosed and untreated because screening tools for depression or anxiety symptoms are not routinely used in clinical practice. It also might be masked by physcial symptoms such as decrease in exercise tolerance, breathlessness, fatigue and increase dependency in daily activities. Anxiety is feeling of apprehension, it occur in 10-33\%, while depression is feeling of helplessness, hopelessness, and frustration, it occur in $6-42 \%$ of COPD patients. ${ }^{2}$ Presence of anxiety 
or depression in COPD is associated with exacerbation of disease, which can accelerate the decline in lung function, thus negatively impacting the patient's quality of life. ${ }^{3}$

To detect anxiety and depression in the COPD population, the American College of Chest Physicians (ACCP) and Global Initiative for Chronic Obstructive Lung Disease (GOLD) recommend the use of the Hospital Anxiety and Depression Scale (HADS). ${ }^{2}$ It contains 2 major components, Anxiety (HADS-A) and depression (HADS-D), each consists of 7 items. The higher the scores obtained, the more severe the symptoms. ${ }^{4}$

Pulmonary Rehabilitation (PR) has become an important part of the management of COPD. Breathing exercises as one of its components can reduce the symptoms of shortness of breath in COPD patients. The Pursed Lip Breathing (PLB) technique can extend the exhalation time, thereby reducing the frequency of respiratory rate and shortness of breath. Inspiratory Muscle Training (IMT) increases the strength and endurance of inspiratory muscle function, increases exercise capacity and reduces shortness of breath. ${ }^{5,6}$ Although it is well known that PR has been shown positive effects on reduce of anxiety and depression in COPD patients ${ }^{6}$, only few studies have studied the effects of specific breathing exercises on it. The goal of this study was to determine the effect of IMT intervention on anxiety and depression in patients with COPD that received PLB training.

\section{METHOD}

This study was an experimental study with pre and post-test group, in August until
September 2019. Participants were recurited from Pulmonary Clinic of Tugurejo Hospital Semarang. All subjects were given an informed consent before they participated. This study has received Ethical Clearance approval from the Health Research Ethics Commission of Tugurejo Hospital Semarang.

The inclusion criteria were outpatients with COPD as evidenced by the post-bronchodilator FEV1 / FVC ratio $<0.70$, GOLD criteria 3 and 4, Maximal Inspiratory Pressure (MIP) value $\leq 60 \mathrm{cmH}_{2} \mathrm{O}$, age $40-65$ years, do not smoke at least the last 3 months, can understand and follow commands, able to walk without tools, willing to participate in research by filling in informed consent. The exclusion criteria were history of exacerbation in the past 6 weeks before the study or being in an exacerbation state, blood pressure $>160 / 100 \mathrm{mmHg}$, arrhythmia, unstable angina, heart failure NYHA degrees 2-4, history of spontaneous pneumothorax, malignancies, nervous and vestibular system disorders, returned smoking during the study period. And for the drop out criteria, participants refused to continue the training session until completion, attendance was less than $80 \%$ or exercises less than 48 times, experience of exacerbation during the study period. Until the end of the study, no subjects were dropped out. Retrieval of research participants was from medical records with a diagnosis of COPD, primary data collection was obtained from history taking, physical examination, spirometry and MIP examination. There were no complaints or side effects during or after the intervention reported by the study subjects.

Twenty COPD patients were randomly divided into control and experimental group. All groups received home program PLB exercises, twice 
a day, morning and evening sessions. Subjects were asked to breathe in through the nose for 2 seconds, then exhale slowly through the pursed lip like blowing out a candle for 4 seconds. Each cycle lasted for 1 minute consists of 8 times inspiration and expiration with 2 seconds rest interval and each session was repeated 2 cycles with 1 minute interval. The experimental group received additional threshold IMT, subjects were asked to inhaled through the mouthpiece of the device at high velocity from residual volume to total lung capacity. Each cycle lasted for 5 minute consists of 3 minute of 8 times inspiration followed 2 minute rest. Each session was repeated 3 cycles, twice daily, starting after a 15 minute interval of PLB exercise. In the first week of IMT exercise, the pressure load was determined to be $30 \%$ from the patient's MIP value. If the patients can tolerate the exercise for 15 minute, the loads will be increased periodically by $4 \mathrm{~cm} \mathrm{H}_{2} \mathrm{O}$ per week starting in the second week. If subjects could not complete it for 15 minute, the pressure load is lowered back to its previous value and use the value until the end of the exercise program period.

Both exercises were done 5 days a week, for 6 weeks. Every 2 times in a week, a joint meeting was held at the Pulmonary Clinic to evaluate the exercises that have been carried out at home and check the diaries that were distributed to each subject. We used HADS to evaluate anxiety and depression status before and after 6 weeks intervention, it took 2-5 minute to complete by participants to fill in. This scale has been widely used in many countries and it has been validated in the hospitals and primary care settings.7 Data were analyzed using were performed with SPSS, version 20. Mann Whitney test, Independent t-test, and Paired t-test were used to compare scores (Anxiety subscale and Depression subscale in HADS) before and after intervention and the differences of decrease in HADS scores between all groups. P value $<0,05$ was considered statistically significant.

\section{RESULT}

This study consisted of 20 COPD patients, 15 male and 5 female. No statistically significant differences between the groups were found in at baseline. The descriptive analysis result of age, sex, BMI, smoking history and FEV1 as a whole can be seen in Table 1. There were no significant differences of HADS-A score at baseline $(p=0.416)$ or after 6 weeks intervention $(p=0,710)$ between both group. After intervention, the HADS-A score in both experimental and control group decreased significantly. However, the delta of HADS-A score in the experimental group was greater than control group with $\mathrm{p}$ value $<0.05$. (Table 2). There were no significant differences of HADS-D score at baseline $(p=0.199)$ or after 6 weeks intervention $(p=0,672)$ between both group. After intervention, the HADS-D score in both experimental and control group decreased significantly. However, the delta of HADS-D score in the experimental group was greater than control group with $p$ value $<0.05$. (Table 3 ).

\section{DISCUSSION}

A complex, circular relationship exists between COPD and psychiatric disorders. The abnormal breathing pattern due to hyperventilation in COPD causes dyspnea and anxiety, the presence of hypocapnia accentuates feelings of anxiety and shortness of breath, resulting 
in a vicious cycle. Dyspnea appears to be the main mechanistic link between COPD and anxiety disorders, although the severity of dyspnea does not always correlate with the severity of anxiety symptoms. COPD leads to immense fatigue and impaired mobility. These cause a decline in functional, social and work independence, that will causes or exaggerates feelings of depression. Persistent hypoxia in the brain can lead to changes in white matter and endothelial, as well as oxidative stress. This can result in mood changes and decreased executive functioning. The chronic systemic inflammatory state realted COPD (with elevated C-reactive protein and cytokine levels) has been suggested as a cause of increased rates of depression. Medicines used to treat COPD on their own can trigger or worsen mood disorders and lead to depression. ${ }^{8}$ Several studies have shown an association of breathlessness with symptoms of depression, anxiety, fatigue, difficulty sleeping, pain and decreased quality of life (QoL). ${ }^{5}$ Pulmonary rehabilitation has been shown to reduce symptoms of anxiety and depression in patients with moderate to severe COPD. ${ }^{9}$

Breathing exercises as part of pulmonary rehabilitation can reduce breathlessness, because slow breathing and higher tidal volumes will increase the respiratory sinus arrhythmia amplitude, improve oxygen uptake, adjust the autonomic nervous system and helps create a better emotional state through interaction between the body and the brain. ${ }^{10}$ Various breathing exercises have been used to improve breathlessness, well known exercises such as PLB and IMT. ${ }^{11}$

Table 1. Baseline demographic and clinical characteristics of study participants

\begin{tabular}{lccc}
\hline Variabel & Experimental & Control & p \\
\hline Age (year) & $56,80 \pm 7,10$ & $59,30 \pm 6,63$ & $0,465 \ddagger$ \\
Sex & & & \\
$\quad$ Male & $8(80 \%)$ & $7(70 \%)$ & $1,000 ¥$ \\
$\quad$ Female & $2(20 \%)$ & $3(30 \%)$ & \\
BMI (kg/m2) & $19,47 \pm 3,86$ & $18,02 \pm 3,01$ & $0,290 \ddagger$ \\
Smoking History & & & \\
$\quad$ User Smoker & $7(70 \%)$ & $7(70 \%)$ & $1,000 ¥$ \\
Passive smoker & $3(30 \%)$ & $3(30 \%)$ & \\
FEV1 (\%) & $31,20 \pm 10,24$ & $28,80 \pm 10,49$ & $0,611 \S$ \\
\hline
\end{tabular}

$¥$ Chi square; $\S$ Independent t; $\$$ Mann whitney, FEV1 = Forced Expiratory Volume First Time 
Table 2. Anxiety Subscale in HADS at baseline and 6th week intervention

\begin{tabular}{lccc}
\hline HADS-A & Experimental & Control & P \\
\hline Pre intervention & $8,70 \pm 2,95$ & $7,30 \pm 4,42$ & $0,416 \S$ \\
Post intervention & $4,90 \pm 3,07$ & $5,50 \pm 3,98$ & $0,710 \S$ \\
P Value & $<0,001 \boldsymbol{q}^{*}$ & $0,021 \boldsymbol{q}^{*}$ & \\
$\Delta$ HADS-A & $-3,80 \pm 1,93$ & $-1,80 \pm 2,04$ & $0,046+^{*}$ \\
\hline
\end{tabular}

* Significant $(\mathrm{p}<0,05) ; \S$ Independent $\mathrm{t}$ \$ Mann whitney; ๆ Paired t, HADS-A : Hospital Anxiety and Depression Scale - Anxiety Subscale

Table 3. Depression Subscale in HADS at baseline and 6th week intervention

\begin{tabular}{lccc}
\hline HADS-D & Experimental & Control & P \\
\hline Pre intervention & $6,20 \pm 2,39$ & $4,50 \pm 3,24$ & $0,199 \S$ \\
Post intervention & $3,70 \pm 2,06$ & $3,60 \pm 2,99$ & $0,672 \ddagger$ \\
P Value & $<0,001 \mathbf{q}^{*}$ & $0,007 \dagger^{*}$ & \\
$\Delta$ HADS-D & $-2,50 \pm 1,27$ & $-0,90 \pm 0,57$ & $0,002 \ddagger^{*}$ \\
\hline
\end{tabular}

* Significant $(\mathrm{p}<0,05) ; \S$ Independent $\mathrm{t}$; \$ Mann whitney; ๆ Paired t, HADS-D : Hospital Anxiety and Depression Scale Depression Subscale

Patients with COPD experience dynamic hyperinflation $(\mathrm{DH})$ due to limited expiratory flow that arises from increased airway resistance and decreased lung elasticity. The expiration times is shorted and the respiratory system unable to reach volume of relaxation before the next inspiration. Several studies have shown that PLB can help reduce $\mathrm{DH} .{ }^{12} \mathrm{PLB}$ is a controlled breathing exercise technique that consist of exhaling through tightly pressed (pursed) lip and inhaling through nose with mouth closed. Slow and prolonged expiration can slow the flow of air during exhalation, creating high pressure in the airways and keeping the airways open to avoid a sudden drop in intrapulmonary pressure resulting in collapse of the alveolar and airways. ${ }^{13,14}$ PLB can improve abnormal breathing patterns due to hyperventilation, assist relaxation and reduce hypocapnia so that it can reduce breathing rate and shortness of breath, reduce anxiety and depression in COPD patients. ${ }^{11}$

IMT as part of respiratory muscle training can improve strength and endurance of the respiratory muscles, before the appearance of improvement in shortness of breath. ${ }^{11}$ The principle of IMT is strengthening the inspiratory muscles, the diaphragm and external intercostal muscles, that might produces a decrease in dynamic hyperinflation. ${ }^{15}$ This accomplished by applying an external targetted load in the device during inspiration, to increase the workload of the inspiratory muscles. ${ }^{16}$ IMT can significantly increase blood flow to the leg muscles and endurance, as evidenced by the increased in mileage and functional capacity during the 6-minute walk test. This increased in endurance will increase 
mobility, reduce functional dependence which is one of the triggers for depression and improve quality of life of patients. These findings were in agreement with De Souza et al. who showed that IMT improved MIP, 6MWD, reduced dyspnea and the level of depression in patients with COPD. ${ }^{17,18}$ Nikoletou et al. showed an improvement of MIP and perception of well-being in COPD patients after 7-week IMT programme. A decrease in the perception of breathlessness during daily activities and an increase in health status are the most common well-received effects of IMT. ${ }^{19}$

In this study, there were no significant differences in subject characteristics between the two groups where these variables did not affect the difference in results. Our results showed that first, anxiety and depression subscale in HADS were decreased significantly after intervention; second, difference of decreased HADS scores in experimental group were more significant compared with those in control group over 6 weeks intervention. Therefore, we suggested that pulmonary rehabilitation, especially breathing exercises, is very important given to CPOD patients, where apart from being useful for reducing complaints of breathlessness, it can also help overcome the patient's anxiety and depression problems. Limitation in this study were short duration of intervention, we did not compare how long the subjects had COPD includes related psychological factors and subjectiveness of HADS.

\section{CONCLUSION}

Breathing exercises can reduce anxiety and depression in COPD patients. Improvement of HADS scores after additional IMT was better than PLB only in COPD patients.

\section{REFERENCES}

1. Phan $\mathrm{T}$, Carter $\mathrm{O}$, Waterer G, Chung LP, Hawkins M, Rudd C, Ziman M, Strobel N. Determinants for concomitant anxiety and depression in people living with chronic obstructive pulmonary disease. Journal of psychosomatic research 2019;120:60-5.

2. Yohannes AM, Willgoss TG. Diagnostic Tools for Anxiety and Depression. In : Sharafkhaneh A, Yohannes AM, Hanania NA, Kunik ME, editors. Depression and Anxiety in Patients with Chronic Respiratory Diseases. USA: Springer Nature; 2017.p.33-55.

3. Montserrat-Capdevila J, Godoy P, Marsal JR, Barbé F, Pifarré J, Alsedà M, Ortega M. Overview of the impact of depression and anxiety in chronic obstructive pulmonary disease. Lung 2017;195(1):77-85.

4. Korkmaz Ekren P, Gürgün A, Elmas Uysal F, Tuncel Ş, Deniz S, Karapolat H, Bacakoğlu F. Effects of pulmonary rehabilitation in patients with mild-to-moderate chronic obstructive pulmonary disease: Bottom of an iceberg. Turkish Journal of Physical Medicine and Rehabilitation 2018;64(2):162-9.

5. Charususin N, Gosselink R, Decramer M, McConnell A, Saey D, Maltais F, Derom E, Vermeersch S, van Helvoort H, Heijdra Y, Klaassen M, Glöckl R, Kenn K, Langer D. Inspiratory muscle training protocol for patients with chronic obstructive pulmonary disease (IMTCO study): a multicentre randomised controlled trial. BMJ open 2013;3(8):e003101.

6. Gordon CS, Waller JW, Cook RM, Cavalera SL, Lim WT, Osadnik CR. Effect of pulmonary rehabilitation on symptoms of anxiety and depression in COPD: a 
systematic review and meta-analysis. Chest 2019; 156(1):80-91.

7. Stern AF. The Hospital Anxiety and Depression Scale. Journal of Occupational Medicine 2014;64(5) :393-4.

8. Hashir M, Nadeem T. Anxiety and Depression in COPD Patients. In : Sharafkhaneh A, Yohannes AM, Hanania NA, Kunik ME, editors. Depression and Anxiety in Patients with Chronic Respiratory Diseases. USA: Springer Nature; 2017.p.57-72.

9. Cafarella PA, Effing TW, Usmani ZA, Frith PA. Treatments for anxiety and depression in patients with chronic obstructive pulmonary disease: a literature review. Respirology 2012;17(4):627-38.

10. Tonhajzerova I, Mestanik M, Mestanikova A, Jurko A. Respiratory sinus arrhythmia as a non-invasive index of 'brain-heart' interaction in stress. The Indian journal of medical research 2016;144(6):815-22.

11. Borge CR, Hagen KB, Mengshoel AM, Omenaas E, Moum T, Wahl AK. Effects of controlled breathing exercises and respiratory muscle training in people with chronic obstructive pulmonary disease: results from evaluating the quality of evidence in systematic reviews. BMC pulmonary medicine 2014;14(1):1-15.

12. Rudi H, Soedarsono S, Makhfudli M. Effect OfPursed Lips Breathing for Peak Expiratory Flow Rate, Oxygen Saturation, Dynamic Hyperinflation: Systematic Review. The 9th International Nursing Conference: Nurses at The Forefront in Transforming Care, Science, and Research; 07-08 April. Surabaya 2018.

13. Zhang W, MehtaA. The historical perspective on pursed lip breathing exercises and its role in pulmonary rehabilitation programs. Medical Research Archives 2018;6(8):1-9.
14. Holland AE, Hill CJ, Jones AY, McDonald CF. Breathing exercises for chronic obstructive pulmonary disease. Cochrane Database of Systematic Reviews 2012(10).

15. Beaumont $M$, Mialon $P$, Le Ber $C$, Le Mevel P, Péran L, Meurisse O, MorelotPanzini C, Dion A, Couturaud F. Effects of inspiratory muscle training on dyspnoea in severe COPD patients during pulmonary rehabilitation: controlled randomised trial. European Respiratory Journal 2018;51(1).

16. O'Connor C, Lawson R, Waterhouse J, Mills GH. Is inspiratory muscle training (IMT) an acceptable treatment option for people with chronic obstructive pulmonary disease (COPD) who have declined pulmonary rehabilitation (PR) and can IMT enhance PR uptake? A single-group prepost feasibility study in a home-based setting. BMJ open 2019;9(8):e028507.

17. De Souza Y, Medeiros S, Da Silva KM, Macedo J, Condesso D, Figueira B, Cruz A, Soares J, Gosselink R, Costa C. Does inspiratory muscle training (IMT) reduce depression in patients with COPD? European Respiratory Journal 2019;54(63) :PA2197.

18. Ubolnuar N, Tantisuwat A, Thaveeratitham P, Lertmaharit S, Kruapanich C, Mathiyakom W. Effects of breathing exercises in patients with chronic obstructive pulmonary disease: systematic review and meta-analysis. Annals of rehabilitation medicine 2019;43(4) :509-23.

19. Nikoletou D, Man WD, Mustfa N, Moore J, Rafferty G, Grant RL, Johnson L, Moxham J. Evaluation of the effectiveness of a home-based inspiratory muscle training programme in patients with chronic obstructive pulmonary disease using multiple inspiratory muscle tests. Disability and Rehabilitation.2016;38(3):250-9. 